Dody Tri Purnawinata, Aspek Hukum Dalam Perjudian Secara Online, Halaman 252-271

\title{
ASPEK HUKUM PIDANA DALAM PERJUDIAN SECARA ONLINE
}

\author{
Dody Tri Purnawinata \\ Sekolah Tinggi Ilmu Hukum Serasan \\ E-mail: dodytriputrawinata@perguruanserasan.ac.id
}

\begin{abstract}
Advances in the world of information and technology provide a new way of online gambling. There are many difficulties in uncovering an online gambling case either to determine the perpetrators of online gambling as well as to determine the place and time of the occurrence of a criminal act of online gambling as well as legal liability for the offender. The materials used in this law research are primary legal materials, secondary, and tertiary. The collection of legal materials research done by identifying, inventorying legislation, researching material library, reading books and other resources related to the problem being studied. Legal materials that have been collected and processed with the interpretation of legal materials and then deduced to draw conclusions about determining the perpetrators, determining locus and tempus delicti and legal liability of online gambling as criminal act in normatif explanantion. The result of this study that in determining the perpetrators of online gambling should be filled ellement are attached to the subject of law (subjective) and attached to the deed (objective), in this case commonly used theories in Indonesia related to locus and tempus delicti can be used in determining locus and tempus delicti relating to the competence of the court,although with advances in technology make it possible for the perpetrator to decieve the real locus and tempus. Legal liability of the offender based on person's condition to be liable for their actions regardless of their justification and excuse.
\end{abstract}

Keywords: Online Gambling; Aspects of Criminal Law

\section{Abstrak}

Kemajuan dalam dunia informasi dan teknologi melahirkan sebuah cara baru dalam melakukan perjudian yaitu perjudian secara online. Cara baru tersebut memunculkan banyak kesulitan dalam mengungkap sebuah kasus perjudian secara online baik itu untuk menentukan pelaku perjudian secara online maupun untuk menentukan tempat dan waktu terjadinya serta pertanggungjawaban hukum bagi pelaku perjudian secara online. Penelitian hukum ini menggunakan bahan hukum primer, sekunder, dan tertier. Pengumpulan bahan hukum dilakukan dengan cara mengidentifikasi, menginventarisasi peraturan perundang-undangan, melakukan studi pustaka, dan sumber-sumber lainnya yang berhubungan dengan masalah yang dikaji. Bahan hukum yang telah dikumpulkan kemudian diolah dengan menginterpretasi bahan-bahan hukum dan kemudian dideduksi untuk menarik kesimpulan. Dari hasil penelitian ini didapat kesimpulan bahwa dalam menentukan pelaku perjudian secara online harus dipenuhi unsur-unsur tindak pidana yang disangkakan terhadap pelaku, baik itu unsur yang melekat pada subjek hukum (subjektif) maupun yang melekat pada perbuatan (objektif). Penentuan locus dan tempus delicti berkaitan dengan kompetensi pengadilan yang berhak untuk mengadili perkara dilakukan dengan menggunakan teori-teori locus dan tempus delicti yang umum digunakan di Indonesia meskipun dengan kemajuan teknologi memungkinkan pelaku untuk mengaburkan tempus dan locus delicti yang sebenarnya. Pertanggungjawaban hukum pelaku tindak pidana perjudian secara online didasarkan pada kondisi seseorang untuk dapat dimintakan pertanggungjawaban atas tindakannya dan terlepas dari adanya alasan pembenar dan pemaaf. Aturan hukum tentang perjudian secara online masih perlu untuk disempurnakan dan mendapat perhatian lebih dari pemerintah dikarenakan masih terdapat banyaknya kelemahan dalam aturan hukum yang telah ada.

Kata Kunci : Perjudian Secara Online; Aspek Hukum Pidana 
Dody Tri Purnawinata, Aspek Hukum Dalam Perjudian Secara Online, Halaman 252-271

\section{PENDAHULUAN}

\section{A. Latar Belakang}

Perilaku dan kebiasaan manusia yang gemar mengadu nasib dan peruntungan melalui permainan telah terjadi sepanjang sejarah peradaban manusia, perilaku seperti ini terjadi di seluruh lapisan dan strata masyarakat, dari yang kaya hingga yang miskin, dari perjudian dengan resiko kecil hingga mempertaruhkan sesuatu yang besar. Perjudian merupakan salah satu masalah dalam masyarakat yang sangat sulit dihilangkan, dalam hal ini perjudian dinilai membawa dampak buruk terutama terhadap pelaku perjudian itu sendiri dan bagi orangorang disekitarnya. Pemerintah Indonesia mengatur masalah perjudian dalam Kitab Undang-Undang Hukum Pidana (untuk selanjutnya disingkat KUHP) pasal 303, undang-undang ini mengatur tentang larangan untuk melakukan perjudian di Indonesia.

Di Indonesia sendiri pada tahun 2008 telah lahir Undang-undang Republik Indonesia Nomor 11 Tahun 2008 tentang Informasi dan Transaksi Elektronik (untuk selanjutnya disingkat UU ITE) yang dalam pertimbangannya dinyatakan bahwa perkembangan dan kemajuan teknologi informasi yang demikian pesat telah menyebabkan perubahan kegiatan kehidupan manusia dalam berbagai bidang yang secara langsung telah mempengaruhi lahirnya bentuk-bentuk perbuatan hukum baru, dan bahwa pemerintah perlu mendukung pengembangan teknologi informasi melalui infrastruktur hukum dan pengaturannya sehingga pemanfaatan teknologi informasi dilakukan secara aman untuk mencegah penyalahgunaannya dengan memperhatikan nilai-nilai agama dan sosial budaya masyarakat Indonesia.

Dalam hal maraknya perjudian di internet, Indonesia tidak ketinggalan pula untuk melakukan penanggulangan dan pencegahan melalui hukum positif yaitu sebagaimana diatur dalam Pasal 27 ayat (2) UU ITE yang berbunyi: "setiap orang dengan sengaja dan tanpa hak mendistribusikan dan/atau mentransmisikan dan/atau membuat dapat diaksesnya informasi elektronik danatau dokumen elektronik yang memiliki muatan perjudian."

Ancaman pidana dari Pasal 27 ayat (2) UU ITE bersumber pada Pasal 45 ayat (1) UU ITE, yang berbunyi: "setiap Orang yang memenuhi unsur sebagaimana dimaksud dalam Pasal 27 ayat (1), ayat (2), ayat (3), atau ayat (4) 
Dody Tri Purnawinata, Aspek Hukum Dalam Perjudian Secara Online, Halaman 252-271

dipidana dengan pidana penjara paling lama 6 (enam) tahun dan/atau denda paling banyak Rp.1.000.000.000,00 (satu miliar rupiah)."

Dalam kenyataannya kegiatan di dunia maya tidak lagi sederhana karena kegiatannya tidak lagi dibatasi teritorial suatu negara, yang mudah diakses kapan pun dan dari mana pun. Disamping itu, pembuktian merupakan faktor yang sangat penting, mengingat informasi elektronik bukan saja belum terakomodasi dalam sistem hukum acara Indonesia secara komprehensif, melainkan juga ternyata sangat rentan untuk diubah, disadap, dipalsukan, dan dikirim ke berbagai penjuru dunia dalam hitungan detik. Dengan demikian, dampak yang diakibatkannya pun bisa demikian kompleks dan rumit.

\section{B. Perumusan Masalah}

Berdasarkan latar belakang di atas, dapat ditarik rumusan masalah sebagai berikut :

1. Bagaimana menentukan pelaku tindak pidana perjudian secara online?

2. Bagaimana menentukan locus dan tempus tindak pidana perjudian secara online?
3. Bagaimana

pertanggungjawaban hukum pelaku tindak pidana perjudian secara online?

\section{Metode Penelitian}

Jenis penelitian tesis ini adalah penelitian hukum normatif. Menurut Jhony Ibrahim penelitian hukum normatif adalah suatu prosedur penelitian ilmiah untuk menemukan kebenaran berdasarkan logika keilmuan hukum dari sisi normatifnya. Logika keilmuannya dalam penelitian hukum normatif dibangun berdasarkan disiplin ilmiah dan cara-cara kerja ilmu hukum normatif, yaitu ilmu hukum yang sui generis. ${ }^{1}$ Maksudnya adalah ia tidak dapat dibandingkan dengan ilmuilmu lain. Fokus kajiannya adalah hukum positif. ${ }^{2}$ Sehubungan dalam penelitian ini, karena yang dikaji mengenai aspek hukum pidana dalam tindak pidana perjudian secara online yang diatur dalam Pasal 27 ayat (2) UU ITE, maka tepatlah jenis penelitiannya adalah penelitian hukum normatif karena fokus kajiannya hukum positif yaitu UU ITE.

Penelitian hukum adalah satu proses untuk menemukan aturan

\footnotetext{
${ }^{1}$ Jhony Ibrahim, Teori Dan Metode Penelitian Hukum Normatif (Malang: Bayumedia, 2006).

2 Bahder Johan Nasution, Metode Penelitian Ilmu Hukum (Bandung: Mandar Maju, 2008).
} 
Dody Tri Purnawinata, Aspek Hukum Dalam Perjudian Secara Online, Halaman 252-271

hukum, prinsip-prinsip hukum maupun doktrin-doktrin hukum guna menjawab isu hukum yang dihadapi ${ }^{3}$. Agar mendapat kebenaran ilmiah yang diharapkan, maka penelitian ini secara umum menggunakan pendekatan perundang-undangan

(Statute Approach $)^{4}$. Pendekatan ini digunakan untuk mempelajari dan menelaah dasar ontologis lahirnya dan landasan filosofis undang-undang serta ratio legi (dasar hukum) dari ketentuan undangundang. Pendekatan UU ITE dan KUHP Pasal 303 mengenai perjudian serta peraturan-peraturan lainnya yang ada hubungannya.

Di samping pendekatan perundang-undangan, penulis juga menggunakan pendekatan konseptual (conceptual approach), pendekatan kasus (case approach). Pendekatan konseptual ini digunakan untuk mengkaji pandangan-pandangan dan doktrin-doktrin yang berkembang. Tujuan pengkajian ini untuk menemukan dan menganalisa ide-ide yang melahirkan pengertian hukum, konsep-konsep hukum, teori-teori hukum dan prinsip-prinsip hukum serta aturan hukum yang berhubungan

\footnotetext{
${ }^{3}$ Eriyantouw Wahid, Keadilan Restoratif dan Peradilan Konvensional dalam Hukum Pidana (Jakarta: Univ. Trisakti, 2009).

${ }^{4}$ Eriyantouw
}

dengan perjudian secara online di Indonesia. Pendekatan konseptual juga dilakukan apabila peneliti tidak beranjak dari aturan hukum yang telah ada.

\section{PEMBAHASAN}

\section{A. Pelaku Tindak Pidana Perjudian Secara Online}

Ajaran mengenai penyertaan di dalam KUHP membagi pelaku tindak pidana menjadi beberapa golongan, yaitu :

1. Pleger / dader atau pelaku;

2. Doenpleger atau orang yang menyuruh melakukan;

3. Medepleger atau orang yang turut serta;

4. Uitlokker atau orang yang menganjurkan.

Sedangkan pembantu atau medeplichtige adalah:

1. Pembantu pada saat kejahatan dilakukan; dan

2. Pembantu sebelum kejahatan dilakukan;

Simons sebagaimana dikutip oleh Eddy O.S. Hiariej mengemukakan bahwa Bij de leer der deelneming worden gemenlijk twee voormen van deelneming onderscheiden, de zelfstandige en de onzelfstandige 
Dody Tri Purnawinata, Aspek Hukum Dalam Perjudian Secara Online, Halaman 252-271

deelneming (dalam ajaran penyertaan biasanya dibagi dalam dua bentuk penyertaan, penyertaan yang berdiri sendiri dan penyertaan yang tidak berdiri sendiri). ${ }^{5}$ Penyertaan yang berdiri sendiri adalah tindakan masingmasing peserta dalam melakukan suatu tindak pidana diberi penilaian atau kualifikasi tersendiri dan tindakan mereka masing-masing diadili secara sendiri pula. Sedangkan penyertaan yang tidak berdiri sendiri adalah dapat/tidaknya seorang peserta dihukum tergantung pada peranannya dalam tindak pidana yang telah dilakukan oleh seorang pelaku dan tergantung pula apakah perbuatan yang dilakukan itu merupakan suatu tindak pidana atau bukan.

\begin{tabular}{|c|c|c|}
\hline Penulis & mengambil & sebuah \\
\hline kasus & perjudian & terkai \\
\hline keberadaan & & webs \\
\hline www.mansion8 & yang & \\
\hline
\end{tabular}

2014. Dalam putusan Pengadilan Negeri Jakarta Utara Nomor 1133/Pid.B/2014/PN Jkt.Utr tanggal 27 Oktober 2014 dengan terdakwa Stefanus Rocky, Marvin Tanjung, Fernandez, Judianto, dan April Yanti

5 Eddy O.S.Hiariej. Prinsip-prinsip Hukum Pidana (Yogyakarta: Cahaya Atma Pustaka, 2014). didakwa oleh Penuntut Umum dengan dakwaan yang berbentuk subsideritas yaitu :

- Kesatu primer melanggar pasal 303 ayat (1) ke-1 KUHP jo Pasal 64 ayat (1) KUHP:

- Kesatu Subsider melanggar Pasal 303 ayat (1) ke-2 KUHP jo Pasal 64 ayat (1) KUHP, atau;

- Kedua melanggar Pasal 27 ayat (2) jo Pasal 45 ayat (1) UU No. 11 Tahun 2008 jo Pasal 55 ayat (1) ke-1 KUHP, atau;

- Ketiga Primer melanggar Pasal 10 jo Pasal 3 UU No.8 Tahun 2010, atau;

- Ketiga Subsider melanggar Pasal 10 jo Pasal 5 UU No. 8 Tahun 2010.

Dalam putusannya, hakim menyatakan bahwa para terdakwa tidak terbukti melakukan tindak pidana Kesatu Primer, Kesatu Subsider, Ketiga Primer, dan Ketiga Subsider, dan kemudian menyatakan bahwa para terdakwa terbukti secara sah dan menyakinkan bersalah melakukan tindak pidana Kesatu Subsider yaitu melanggar Pasal 303 ayat (1) ke-2 KUHP jo Pasal 64 ayat 1 KUHP dan menjatuhkan pidana terhadap para terdakwa dengan pidana penjara masing-masing selama 1 (satu) bulan dan 20 (dua puluh) hari. 
Dody Tri Purnawinata, Aspek Hukum Dalam Perjudian Secara Online, Halaman 252-271

Berdasarkan bukti-bukti yang ada dan didukung oleh fakta di persidangan, seharusnya para terdakwa dapat dijerat dengan Pasal 27 ayat (2) jo Pasal 45 ayat (1) UU ITE jo Pasal 55 ayat (1) ke-1 KUHP dengan ancaman pidana penjara paling lama 6 (enam) tahun dan/atau denda paling banyak Rp.1.000.000.000 (Satu Milyar Rupiah). Dari fakta persidangan diketahui bahwa para pelaku bersamasama dengan Lucas Atjep Soegandi, Patrick Antonius, Achad Hakim (didakwa dengan berkas terpisah) dan Henry Cahyadi (DPO) menjalankan website www.mansion88.com yang mengandung unsur perjudian di dalamnya, serta dengan sengaja mendistribusikan, mentransimisikan, dan membuat dapat diaksesnya website yang bermuatan perjudian. Dalam melakukan tindak pidana perjudian secara online ini para terdakwa ada yang berperan sebagai pemilik website, bagian promosi website, dan bagian administrasi. Dari hasil penyidikan didapat pula barang bukti berupa komputer, media penyimpanan, rekening bank, serta 5 buah server yang digunakan dalam tindak pidana perjudian secara online.

\section{Plegen}

Terdapat beberapa ahli yang mengemukakan pendapatnya mengenai Plegen (yang melakukan) atau Pleger (pelaku).

Hazewinkel-Suringa menyatakan bahwa pelaku adalah setiap orang yang dengan seorang diri telah memenuhi semua unsur delik seperti yang ditentukan. Berbeda dengan Suringa adalah Pompe yang menyatakan sebagai berikut, pelaku adalah semua orang yang disebut dalam pasal 55 KUHP, hal ini diperkuat oleh MvT yang menyatakan bahwa semua orang yang telah disebutkan dalam pasal 55 KUHP adalah pelaku. Van Bemmelen dan Van Hattum kemudian mendefinisikan pelaku : pelaku adalah orang yang memenuhi suatu rumusan delik atau orang yang memenuhi semua unsur dari rumusan delik, ataupun seperti yang dikatakan Zevenbergen: orang yang telah memenuhi semua unsur dari suatu delik secara lengkap. ${ }^{6}$

Dalam kasus terkait putusan pengadilan nomor 1133/Pid.B/2014/PN Jkt.Utr pihak penyidik dapat melakukan penyidikan lebih lanjut mengenai kepemilikan website www.mansion88.com dari data pendaftaran serta rekening bank yang

${ }^{6}$ Eddy 
Dody Tri Purnawinata, Aspek Hukum Dalam Perjudian Secara Online, Halaman 252-271

dipakai untuk membiayai Terkait dengan konteks beroperasinya website tersebut yang didapat dari hasil penyidikan. Dapat dikatakan bahwa pemilik website www.mansion88.com adalah pelaku utama dalam kasus tersebut

\section{Doenplegen}

Doenplegen juga disebut sebagai middelijk daderschap yang berarti seseorang mempunyai kehendak melakukan suatau perbuatan pidana, namun ia tidak mau melakukannya sendiri dan mempergunakan orang lain yang disuruh melakukan perbuatan pidana tersebut. Kendati demikian, seseorang yang menyuruh orang lain melakukan suatu perbuatan, sama halnya dengan orang tersebut melakukan perbuatan itu sendiri: qui per alium facit per seipsum facere videtur. Paling tidak ada tiga syarat penting dalam doenplegen. Pertama, alat yang dipakai untuk melakukan suatu perbuatan pidana adalah orang. Kedua, orang yang disuruh tidak mempunyai kesengajaan, kealpaan atau kemampuan bertanggung jawab. Ketiga, sebagai konsekuensi syarat kedua adalah bahwa yang disuruh melakukan tidaklah dapat dijatuhi pidana. perjudian secara online, orang yang menyuruh untuk mendistribusikan, mentransmisikan, ataupun membuat dapat diaksesnya konten yang bermuatan perjudian dapat dikategorikan sebagai doenplegen. Sebagai contoh : Andi menyuruh Budi untuk membuat dan mengoperasikan sebuah website yang bermuatan perjudian di dalamnya. Maka Andi termasuk dalam kategori orang yang menyuruh untuk melakukan (doenplegen).

\section{Medeplegen}

Medeplegen dapat diartikan sebagai turut serta melakukan. Mengenai istilah medeplegen, pada awalnya digunakan kalimat "opzettelijk tot het plegen daarvan medewerken" sengaja ikut bekerja untuk melakukan perbuatan. Istilah tersebut mendatangkan keberatan karena tidak terlihat perbedaan dengan pembantu yang memberikan bantuan pada saat perbuatan dilakukan. Berdasarkan saran De Vries, seorang ahli bahasa, sehingga kata "medewerken" diganti dengan istilah medeplegen. Bentuk penyertaan medeplegen ini tidak dinyatakan secara expressive verbis dalam Code Penal Perancis, namun 
Dody Tri Purnawinata, Aspek Hukum Dalam Perjudian Secara Online, Halaman 252-271

diakui dalam yurisprudensi. ${ }^{7}$ Oleh karena itu tidak ada kesatuan pendapat di antara para ahli hukum pidana terkait apa yang dimaksud dengan medeplegen.

Dalam kasus putusan pengadilan nomor 1133/Pid.B/2014/PN Jkt.Utr dapat dikatakan bahwa seluruh terdakwa secara bersama-sama turut serta dalam mendistribusikan, mentransmisikan, dan membuat dapat diaksesnya website www.mansion88.com yang bermuatan perjudian.

\section{Uitlokking}

Uitlokking secara harfiah diartikan sebagai yang menganjurkan atau menggerakkan, sedangkan orang yang menganjurkan atau menggerakkan disebut uitlokker.

Terdapat dua bentuk pembantuan. Pertama, pembantuan pada saat kejahatan dilakukan. Kedua, pembantuan untuk melakukan kejahatan. Artinya, pembantuan itu diberikan sebelum kejahatan terjadi, apakah dengan memberi kesempatan, sarana atau keterangan untuk melakukan kejahatan. Pembantuan untuk melakukan pelanggaran tidaklah dipidana. Seseorang tidak bisa disebut sebagai pelaku pembantu hanya karena ia kenal pelaku utamanya, namun pembantuan harus tahu apa yang ia perbuat dan dengan cara apa membantunya. Sebagaimana prinsip hukum nullus dicitur accessories post feloniam sed ille qui novit principalem feloniam fecisse, et illum receptavit et comfortavit (no one is called an accessory after the fact but that person who knew the principal to have committed a felony, and received and comforted him). ${ }^{8}$

Pada perjudian secara online terdapat penyedia layanan perjudian secara online dan pemakai layanan perjudian secara online. Penyedia layanan perjudian secara online memerlukan sebuah komputer server yang dapat melayani permintaan untuk mengakses perjudian secara online dalam skala besar, pemilik layanan perjudian secara online juga memiliki website perjudian secara online yang dapat diakses oleh pengguna layanan perjudian secara online. penyedia layanan perjudian secara online di Indonesia terkadang memilih untuk menyewa server yang terletak di luar wilayah yurisdiksi negara Indonesia untuk menghindari penegak hukum,

8 Bryan A.Garner, Black's Law Dictionary (USA : Thomson \& West, 1999). 
Dody Tri Purnawinata, Aspek Hukum Dalam Perjudian Secara Online, Halaman 252-271

penyedia layanan perjudian secara online cenderung memilih untuk menyewa server yang terletak di negara-negara yang memperbolehkan perjudian, di dalam server inilah tersimpan semua data pemain, daftar rekening yang dipakai, dan semua data terkait pelayanan perjudian secara online ini.

Penyedia layanan perjudian secara online juga memiliki sebuah website sebagai penghubung antar muka pengguna layanan perjudian secara online dan melalui layanan antar muka inilah pengguna dapat mengakses perjudian secara online. Website yang dibuat oleh penyedia layanan perjudian kemudian diletakkan di dalam server yang telah disewa oleh penyedia layanan tadi sehingga ketika dilakukan pemeriksaan terlihat bahwa server dan website domain layanan perjudian secara online tersebut berada di luar wilayah Indonesia. pengelola layanan perjudian secara online kemudian memantau server dan website serta para pemakai layanan perjudian secara online melalui komputer yang memiliki akses terhadap server perjudian secara online. sistem yang dipakai untuk mengendalikan perjudian secara online sudah dibuat sedemikian rupa hingga dapat berjalan secara otomatis oleh komputer server, mulai dari mengolah data pemain, mencocokkan data pemain, hingga mengatur data pemain yang melakukan kecurangan dalam perjudian secara online.

Penyedia layanan perjudian secara online harus memiliki seorang teknisi yang ahli dalam bidang komputer untuk memantau kondisi server dan website serta mengatur kondisi server dan layanan agar dapat bekerja sempurna. pengguna layanan perjudian secara online kemudian mengakses website perjudian yang telah disediakan oleh penyedia layanan perjudian secara online dengan terlebih dahulu mendaftarkan diri, memasukkan data-data pengguna dan rekening bank untuk kemudian akan dipergunakan dalam permainan judi. Setelah melakukan pendaftaran melalui website perjudian secara online barulah pemakai layanan perjudian secara online dapat mengakses layanan perjudian dan berinteraksi dengan para pemakai layanan perjudian secara online lainnya. Pada umumnya para pemakai layanan perjudian secara online lebih memilih untuk menyamarkan identitas aslinya untuk 
Dody Tri Purnawinata, Aspek Hukum Dalam Perjudian Secara Online, Halaman 252-271

menghindari pihak penegak hukum baik itu memakai nama pengguna samaran ataupun memakai rekening bank orang lain.

Menurut Budi Suhariyanto dalam pasal 27 ayat (2) UU ITE terdapat celah hukum bagi pihak-pihak yang tidak disebutkan dalam teks pasal tersebut, akan tetapi terlibat dalam acara perjudian di internet. Misalnya para penjudi yang bermain atau menggunakan atau menerima akses informasi elektronik dan/atau dokumen elektronik yang memiliki muatan perjudian. ${ }^{9}$ Oleh karena itu, di dalam perjudian secara online, aturan hukum untuk penjudi yang bermain tetap mengacu pada KUHP.

\section{Pelaku Penyedia Layanan Perjudian Secara Online}

Untuk menetapkan seseorang sebagai pelaku tindak pidana, haruslah dipenuhi unsur-unsur tindak pidana yang disangkakan kepadanya. Oleh karena itu, terhadap penyedia layanan perjudian secara online dikenakan Pasal 27 ayat (2) jo Pasal 303 KUHP. Dalam hal penetapan penyedia layanan perjudian secara online, harus dipenuhi unsur subjektif dan objektif perjudian

\footnotetext{
${ }^{9}$ Budi Suhariyanto, Tindak Pidana Teknologi Informasi (Cybercrime) (Jakarta : Raja Grafindo Persada, 2012).
}

secara online. Selain itu, diperlukan pula pemenuhan unsur yurisdiksi hukum.

Pertama, unsur subjektif perjudian secara online. Unsur subjektif adalah unsur yang melekat pada subjek hukum, dalam hal perjudian secara online adalah sebagai berikut :

a. Setiap Orang

b. Dengan Sengaja dan Tanpa Hak

Pemahaman kesengajan dalam UU ITE mengacu kepada teori-teori kesengajan yang berlaku di Indonesia, yaitu :

- Kesengajan sebagai maksud

- Kesengajan sebagai kepastian

- Kesengajan sebagai kemungkinan

Unsur setiap orang yang mengacu pada orang perorangan (natuurlijk persoon) atau pun badan hukum (recht persoon), harus dipenuhi dalam hal menjerat penyedia layanan perjudian secara online. Sebagaimana telah dijelaskan sebelumnya, bahwa unsur ini menunjuk pada orang/badan hukum yang berada di Indonesia, maupun luar Indonesia yang merugikan kepentingan Indonesia berarti penyedia layanan perjudian secara online yang tidak berada di Indonesia dan bukan warga negara Indonesia pun dapat dijerat dengan UU ITE. 
Dody Tri Purnawinata, Aspek Hukum Dalam Perjudian Secara Online, Halaman 252-271

Kedua, unsur objektif perjudian secara online. Unsur objektif adalah unsur yang melekat pada perbuatan, dalam hal perjudian secara online adalah sebagai berikut :

a. Mendistribusikan

b. Mentransmisikan

c. Membuat Dapat Diaksesnya

d. Informasi atau dokumen elektronik

e. Muatan Perjudian

Mengacu pada Pasal 303 ayat (3) KUHP, yang disebut dengan permainan judi adalah tiap-tiap permainan, dimana pada umumnya kemungkinan mendapat untung tergantung pada peruntungan belaka, juga karena pemainnya lebih terlatih atau lebih mahir. Di situ termasuk segala pertaruhan tentang keputusan perlombaan atau permainan lainlainnya, yang tidak diadakan antara mereka yang turut berlomba atau bermain, demikian juga segala pertaruhan lainnya.

Berdasarkan pasal a quo, yang dimaksud dengan muatan perjudian ialah website perjudian berupa permainan yang di dalamnya ada bursa taruhan yang dibangun oleh seseorang. ${ }^{10}$ Akan tetapi, jika mengacu pada esensi Perjudian maka yang

\footnotetext{
${ }^{10}$ Joshua Sitompul, Cyberspace, Cybercrimes, Cyberlaw (Jakarta : Tatanusa, 2012).
}

dimaksud dengan "Muatan Perjudian" tidak hanya sekedar Website dan bursa taruhan yang ada dalam website, karena bagian penting dari suatu perjudian ialah harus ada memasang taruhan dan adanya hasil dari taruhan tersebut, baik menang maupun kalah.

$$
\text { Selain Pasal } 27 \text { ayat (2) UU }
$$

ITE Jo Pasal 303 KUHP, penyedia layanan perjudian secara online dapat pula dikenakan Pasal 45 ayat (1) UU ITE. Penyedia layanan perjudian secara online mendistribusikan layanan perjudian yang dibuatnya dengan membuat website yang digunakan dan dapat ditemukan dengan mudah oleh mesin pencari (seperti www.google.com atau www.yahoo.com) ataupun dengan memakai jasa pengiklanan yang banyak terdapat di internet, termasuk pendistribusian iklan melalui media sosial, blog, maupun melalui websitewebsite yang menyediakan halaman iklan. Upaya penyedia layanan untuk mentransmisikan jasa perjudian secara online ini juga dapat dilakukan dengan melalui jasa penyedia periklanan global atau melalui jalur transmisi yang tidak terblokir oleh penegak hukum di Indonesia. banyak website yang sengaja menyediakan halaman untuk 
Dody Tri Purnawinata, Aspek Hukum Dalam Perjudian Secara Online, Halaman 252-271

dipergunakan sebagai sarana melakukan tindakan yang bertentangan penempatan iklan dengan imbalan bayaran apabila iklan tersebut diakses atau dilihat oleh pengguna, celah seperti inilah yang digunakan oleh penyedia layanan perjudian secara online untuk mentransmisikan dan mendistribusikan layanan perjudiannya. Untuk membuat dapat diaksesnya konten bermuatan perjudian secara online maka penyedia layanan perjudian secara online memberikan petunjuk kepada pengguna tentang tata cara agar website milik pengguna layanan perjudian secara online dapat diakses meskipun website tersebut sudah diblokir oleh penegak hukum, baik itu dengan menyebarkan artikel, spam, email, maupun dengan membuat blog yang memuat tata cara agar pengguna layanan perjudian secara online dapat mengakses website perjudian bahkan dengan memberikan program khusus yang dibuat agar dapat membuat dapat diaksesnya website milik penyedia layanan perjudian secara online. Berdasarkan praktik distribusi maupun transmisi muatan informasi dan dokumen elektronik yang demikian, penyedia layanan perjudian secara online telah dengan hukum.

Tindakan mendistribusikan, mentransmisikan, dan membuat dapat diaksesnya informasi elektronik dan/atau dokumen elektronik yang bermuatan perjudian oleh penyedia layanan perjudian secara online merupakan tindakan yang bertentangan dengan hukum. Oleh sebab itu, penentuan pelaku yang masuk dalam kategori penyedia layanan perjudian secara online adalah dengan cara mengkonstatir, dan mengkualifisir tindakannya. Hal ini dapat dilakukan dengan penyelidikan terhadap penyedia layanan perjudian secara online dengan bantuan teknologi tertentu berupa tracing (pelacakan) lokasi berdasarkan internet protocol address (IP Address), dan melakukan penyidikan terhadap pemilik layanan perjudian untuk kemudian dikembangan berdasarkan kualifikasi pelaku tindak pidana.

Jika penyedia layanan perjudian secara online adalah materieele dader sebagai pelaku tunggal, maka penyedia layanan perjudian secara online memiliki layanan server tersendiri, admin satu orang. Dalam kerangka yang demikian, maka pelaku adalah orang tunggal sebagai orang yang 
Dody Tri Purnawinata, Aspek Hukum Dalam Perjudian Secara Online, Halaman 252-271

mendistribusikan, mentransmisikan dan membuat dapat diaksesnya informasi elektronik dan/atau dokumen elektronik yang bermuatan perjudian. Namun demikian, praktik penyediaan layanan perjudian secara online sangat tidak mungkin dilakukan oleh satu orang saja. Oleh sebab itu, perlu dikualifisir pelaku yang turut serta melakukan.

Pelaku penyedia layanan perjudian secara online adalah pemilik website, sedangkan yang turut serta melakukan adalah remote admin yang mengatur dan menjalankan aktivitas penyedia layanan perjudian secara online. Remote admin tidak dapat dikualifikasikan sebagai pembantu (medeplichtige), hal ini karena antara pemilik pelayanan perjudian secara online dengan remote admin terdapat kesengajaan untuk berkerja sama, kerjasama yang dilakukan adalah kerjasama erat, ada tindakan pelaksanaan dari remote admin .

\section{Pelaku Pengguna Layanan}

\section{Perjudian Secara Online}

Selain penyedia layanan perjudian secara online, terdapat pula pengguna layanan perjudian secara online (selanjutnya disebut pengguna). Pengguna ini adalah pemain judi atau penjudi yang berdasarkan hukum positif dapat dikenakan Pasal $45 \mathrm{UU}$ ITE maupun Pasal 27 ayat (2) UU ITE Jo Pasal 303 bis KUHP.

Untuk menentukan ada/tidaknya tindak pidana yang terjadi dilakukan melalui penyelidikan, sedangkan untuk menemukan pelaku dan bukti-buktinya dilakukan melalui penyidikan. Persoalan perjudian online terkait pelaku yang posisinya sebagai pengguna bukanlah pada saat pelaku tertangkap tangan melakukan perjudian secara online melainkan upaya pelacakan terhadap pengguna. Hal ini karena untuk menentukan pelaku penegak hukum harus melakukan pelacakan dengan penggunaan teknologi. Dalam konteks yang demikian, penggunaan teknologi ibarat pedang yang bermata dua karena dapat menguntungkan dan pula merugikan. Berdasarkan hal tersebut diperlukan respon hukum yang cepat, yaitu hukum yang mengikuti perkembangan masyarakat dalam konteks teknologi. Hal ini karena diperlukan pengaturan hukum yang memberikan keadilan substantif terhadap persoalan teknologi.

Pemikiran Nonet dan Selznick dan teori substantif tepat untuk dijadikan dasar menentukan pelaku 
Dody Tri Purnawinata, Aspek Hukum Dalam Perjudian Secara Online, Halaman 252-271

tindak pidana perjudian online dalam konteks pengguna. Hal ini karena untuk melakukan penegakan hukum terhadap perjudian online melibatkan pemikiran hukum yang bersifat responsif.

Mengacu pada pemikiran Nonet dan Selznick menyatakan bagi tatanan hukum responsif, hukum merupakan institusi sosial, oleh karena itu, hukum dilihat lebih dari sekedar sistem peraturan belaka, melainkan juga bagaimana hukum menjalankan fungsifungsi sosial dalam dan untuk masyarakatnya. ${ }^{11}$ Dalam konteks pemikiran yang demikian, menjalankan hukum tidak terlepas dari nilai sosial yang ada di masyarakat. Artinya, dalam penetapan pelaku perjudian online dapat saja digunakan instrumen teknologi sebagai suatu dasar pembuktian.

Pembuktian dalam ranah pidana merupakan usaha untuk mencari kebenaran materil tentang: (1) telah terjadinya tindak pidana dan (2) bahwa tersangka (yang kemudian menjadi terdakwa) adalah pelakunya. Kedua hal ini dibuktikan dengan alat-alat bukti serta dikuatkan dengan keyakinan

11 Satjipto Rahardjo, Hukum dan Perubahan Sosial: Suatu Tinjauan Teoritis Serta Pengalaman-Pengalaman di Indonesia (Bandung: Alumni, 1983). hakim melalui satu proses peradilan pidana.

Jika ada seseorang disangka atau didakwa telah melakukan perjudian dalam ruang siber maka Aparat Penegak Hukum harus membuktikan bahwa orang tersebut telah memenuhi seluruh unsur yang diatur dalam Pasal 27 ayat (2) UU ITE. Penyidik dapat melakukan prosedur imaging/kloning data dalam forensik digital terhadap sistem elektronik pelaku misalkan laptop atau komputer yang dimaksud untuk mencari informasi mengenai rekaman aktivitas (log) pelaku. Hasil imaging tersebut dapat dijadikan alat bukti berdasarkan Pasal 5 jo. Pasal 44 UU ITE. Hasil imaging sistem elektronik pelaku, misalnya menunjukkan pelaku telah mengakses sebanyak 56 kali website perjudian.

Aparat Penegak Hukum juga dapat menyita server pengelola perjudian secara online. Penyidik dapat melakukan forensik digital untuk mencari informasi yang membuktikan bahwa pelaku telah mengakses situs tersebut. Hasil imaging terhadap server juga dapat dijadikan alat bukti berdasarkan Pasal 5 jo. Pasal 44 UU ITE sebagaimana telah disebutkan di 
Dody Tri Purnawinata, Aspek Hukum Dalam Perjudian Secara Online, Halaman 252-271

atas. Dari hasil imaging kedua ini, misalkan, ditemukan bahwa pelaku telah berhasil mengakses situs judi sebanyak 56 kali; Dengan demikian hasil imaging terhadap sistem elektronik milik pelaku dan pengelola judi adalah sama. Kesamaan inilah yang dapat dijadikan petunjuk penyidik bahwa salah satu unsur tindak pidana telah terpenuhi.

Unsur kesengajaan juga dapat ditemukan dalam hal sebuah website perjudian mengharuskan pemain judi mengunduh dan meng-install aplikasi perjudian. Apabila penyidik menemukan bahwa seseorang telah mengunduh sebuah aplikasi perjudian dalam laptop atau komputer miliknya, maka penyidik dapat juga menyimpulkan atau mendapatkan petunjuk bahwa unsur kesengajaan telah terpenuhi.

Jika untuk dapat bermain judi pelaku harus mentransfer sejumlah uang yang kemudian dikonversi menjadi koin, dan penyidik dapat menemukan bukti transfer dari pelaku kepada rekening yang digunakan untuk bermain judi. Kemudian penyidik dari hasil imaging server pengelola judi, juga dapat membuktikan adanya bukti transfer dari pelaku dan ada bukti hasil konversi nilai uang menjadi koin judi milik pelaku, maka petunjuk tersebut dapat dijadikan alat bukti, demikian pula hasil imaging-nya.

Aspek Pembuktian dalam Pasal 5 UU ITE mengatur bahwa informasi atau dokumen elektronik, atau hasil cetaknya (yaitu hasil cetak dari informasi dan dokumen elektronik) dapat dijadikan alat bukti hukum yang sah. Informasi elektronik atau dokumen elektronik, atau hasil cetaknya merupakan perluasan dari alat bukti yang sah sesuai dengan hukum acara yang berlaku di Indonesia. Informasi elektronik, dokumen elektronik, dan hasil cetaknya dapat dijadikan alat bukti sepanjang dapat dijaga, antara lain, keutuhan dan ketersediaan dari informasi atau dokumen elektronik tersebut.

B. Menentukan Locus Delicti dan Tempus Tindak Pidana Perjudian Secara Online

Locus Delicti di dalam Black's Law Dictionary diartikan sebagai place of the wrong (the place where an offense was committed; the place where the last event necessary to make the actor liable occurred). Sedangkan tempus diartikan sebagai time; a 
Dody Tri Purnawinata, Aspek Hukum Dalam Perjudian Secara Online, Halaman 252-271

specified duration. ${ }^{12}$ Jika diartikan, locus dan tempus dalam tindak pidana berarti tempat dan waktu terjadinya tindak pidana. Locus penting untuk diketahui karena; menentukan apakah hukum pidana Indonesia berlaku terhadap perbuatan pidana tersebut atau tidak. Ini berhubungan dengan Pasal 2 sampai dengan 8 KUHP; menentukan kejaksaan dan pengadilan mana yang harus mengurus perkaranya. Ini berhubungan dengan kompetensi relatif. Tempus penting untuk diketahui karena; Pasal 1 KUHP (apakah perbuatan yang bersangkut paut pada waktu itu sudah dilarang dan diancam dengan pidana, berkaitan dengan asas legalitas); Pasal 44 KUHP (apakah terdakwa ketika itu mampu bertanggung jawab); Pasal 45 KUHP (apakah terdakwa ketika melakukan perbuatan sudah berumur 16 tahun atau belum); Pasal 79 KUHP (verjaring atau daluarsa, dihitung mulai hari setelah perbuatan pidana terjadi). ${ }^{13}$ Beberapa teori tentang locus delicti yang lazim dipergunakan di Indonesia adalah $^{14}$ :

1. Teori perbuatan materiil (leer van lichamelijke daad).

\footnotetext{
12 Bryan A.Garner, Black's Law Dictionary

13 Moeljatno, Asas-Asas Hukum Pidana (Jakarta: Rineka Cipta, 1993).

14 Sudarto, Hukum Pidana I (Semarang: Yayasan Sudarto, 1990).
}

2. Teori alat yang digunakan (leer van het instrument).

3. Teori akibat (leer van het gevolg)

Penentuan tempat dan waktu terjadinya sebuah tindak pidana perjudian secara online terkadang menyulitkan Aparat Penegak Hukum. Dalam kasus pelaku perjudian secara online tertangkap tangan sedang melakukan perjudian secara online di warung internet dan tempat terbuka lainnya maka penentuan tempat dan waktu terjadinya tindak pidana perjudian secara online dapat ditentukan dengan metode penentuan yang paling cocok. Apabila pelaku sudah tertangkap oleh aparat penegak hukum maka dapat dilakukan pemeriksaan terhadap media komputer ataupun telepon hingga rekening milik tersangka pelaku perjudian secara online. Aparat penegak hukum dapat melakukan Imaging terhadap komputer yang diduga menjadi media untuk melakukan perjudian secara online untuk mencari bukti bahwa komputer tersebut telah digunakan untuk mengakses website perjudian berulang kali, ataupun rekening bank yang telah digunakan untuk mengirimkan sejumlah uang ke rekening tertentu milik penyedia layanan perjudian 
Dody Tri Purnawinata, Aspek Hukum Dalam Perjudian Secara Online, Halaman 252-271

secara online. Dari hasil imaging dapat diketahui pula dimana tepatnya lokasi pelaku melakukan tindak pidana perjudian dan waktu terjadinya tindak pidana perjudian secara online, baik itu berdasarkan alamat IP pengguna ataupun melalui informasi yang di dapat dari $\log$ komputer tersebut.

Dalam kasus yang ditangkap adalah bandar perjudian secara online, maka komputer server perjudian secara online dapat dipakai untuk menjerat pelaku perjudian lainnya, dari data server dapat ditindaklanjuti dengan memeriksa log server yang menyimpan data data pemain dan data rekening yang dipakai untuk mentransfer sejumlah uang kepada penyedia layanan perjudian maupun rekening yang dipakai untuk menerima hasil kemenangan dari perjudian secara online. Dari data server pula dapat dilihat dimana lokasi pemain berdasarkan IP pengguna yang sedang mengakses website yang dikelola oleh server tersebut.

\section{Pertanggungjawaban Hukum \\ Pelaku Tindak Pidana Perjudian \\ Secara Online}

Van Hamel menyatakan bahwa pertanggungjawaban hukum adalah suatu keadaan normal psikis dan kemahiran yang membawa tiga macam kemampuan, yaitu 1) mampu untuk dapat mengerti makna serta akibat sungguh-sungguh dari perbuatanperbuatan sendiri, 2) mampu untuk menginsyafi bahwa perbuatanperbuatan itu bertentangan dengan ketertiban masyarakat, 3) mampu untuk menentukan kehendak berbuat ${ }^{15}$.

\section{Definisi} mengenai

pertanggungjawaban hukum dikemukakan oleh Simons sebagai suatu keadaan psikis, sehingga penerapan suatu ketentuan pidana dari sudut pandang umum dan pribadi dianggap patut. Masih menurut Simons, bahwa dasar adanya tanggung jawab dalam hukum pidana adalah keadaan psikis tertentu pada orang yang melakukan perbuatan pidana dan adanya hubungan antara keadaan tersebut dengan perbuatan yang dilakukan yang sedemikian rupa sehingga orang itu dapat dicela karena nelakukan perbuatan tadi.

Pendekatan sosial budaya merupakan upaya preventif yang dapat dilakukan agar masyarakat tidak tergoda untuk melakukan perjudian baik secara konvensional maupun melalui internet karena itu merupakan

${ }^{15}$ Eddy O.S. Hiariej, Prinsip-Prinsip Hukum Pidana 
Dody Tri Purnawinata, Aspek Hukum Dalam Perjudian Secara Online, Halaman 252-271

suatu kejahatan. Sementara itu pendekatan hukum dilakukan secara represif setelah diketahui adanya tindak pidana perjudian. Untuk mengatasi tindak pidana perjudian secara online yang banyak terjadi saat ini, pemerintah Indonesia telah membuat UU ITE yang di dalamnya mengatur berbagai kegiatan yang dilakukan di dunia maya (cyberspace), termasuk beberapa perbuatan yang dilarang karena melanggar hukum dan mengandung unsur pidana. Walaupun tindak pidana di dunia maya (cybercrime) belum diatur secara khusus dalam suatu peraturan perundang-undangan tertentu, namun telah diatur dalam UU ITE tersebut termasuk tindak pidana perjudian melalui internet ini, antara lain diatur dalam Pasal 27 ayat (2) sebagai perbuatan yang dilarang.

\section{KESIMPULAN DAN}

REKOMENDASI

Berdasarkan pembahasan yang telah dilakukan pada bagian-bagian terdahulu, penulis mendapatkan kesimpulan sebagai berikut :

1. Untuk menentukan pelaku tindak pidana perjudian secara online maka pelaku harus memenuhi unsur-unsur subjektif dan objektif yang terdapat dalam Pasal 27 ayat (2) UU ITE.

2. Untuk menentukan locus delicti dan tempus delicti dalam perkara perjudian secara online masih mengacu kepada pengaturan sebagaimana halnya perjudian secara konvensional, karena tempat dan waktu terjadinya perjudian secara online dapat dimanipulasi dan dikaburkan oleh pelaku dengan menggunakan sarana teknologi baik itu dengan melakukan pemalsuan IP Address hingga memalsukan identitas pelaku tindak pidana perjudian secara online yang sebenarnya ataupun memakai identitas orang lain dalam melakukan tindak pidana perjudian secara online, maka dibutuhkan keahlian khusus dalam bidang teknologi bagi penegak hukum untuk dapat menentukan locus delicti dan tempus delicti yang sebenarnya dengan cara melakukan pelacakan terhadap alamat IP (Tracking IP) ataupun dengan cara lainnya.

3. Pertanggungjawaban hukum pelaku tindak pidana perjudian secara online didasarkan pada 
Dody Tri Purnawinata, Aspek Hukum Dalam Perjudian Secara Online, Halaman 252-271

keadaan atau kondisi seseorang. Seseorang dapat dimintakan pertanggungjawaban hukum atas tindakannya apabila ia secara sadar mengetahui bahwa perbuatan yang dilakukannya adalah perbuatan yang melanggar hukum. Dalam hal perjudian secara online maka pelaku harus secara sadar mengetahui dan menyadari bahwa perbuatan melakukan perjudian secara online, melakukan distribusi, melakukan transmisi konten dengan muatan perjudian adalah bertentangan dengan hukum dan memiliki akibat hukumnya. Maka pelaku perjudian secara online dapat dimintakan pertanggungjawaban hukum terhadap perbuatannya terlepas dari adanya unsur pemaaf maupun unsur pembenar.

Pembuat kebijakan hendaknya memberikan perhatian khusus terhadap pelanggaran dan kejahatan yang terjadi di dunia maya, khususnya perjudian secara online. hal ini dapat dilakukan dengan cara membuat pengaturan khusus yang lebih detail sehingga penegakan hukum dapat berjalan dengan baik. Penegak hukum hendaknya terus melakukan pembenahan dan meningkatkan sumber daya manusia yang mampu dan menguasai bidang informatika serta memiliki sarana dan prasarana yang mumpuni untuk menanggulangi perjudian secara online.

Penyelenggara pelayanan internet di Indonesia hendaknya turut bekerjasama dan berpartisipasi aktif dalam melakukan usaha pencegahan terhadap upaya pendistribusian dan pentransimisian data yang memuat konten yang dilarang di Indonesia. Masyarakat khususnya pengguna layanan Internet hendaknya lebih bijak dalam menggunakan layanan internet. Kesadaran masyarakat akan bahaya dari perjudian merupakan faktor penting dalam menekan berkembangnya perjudian secara online.

\section{DAFTAR PUSTAKA}

Bahder Johan Nasution. Metode Penelitian Ilmu Hukum. Bandung: Mandar Maju, 2008.

Bryan A.Garner. Black's Law Dictionary. USA: Thomson \& West, 1999.

Budi Suhariyanto. Tindak Pidana Teknologi Informasi (Cybercrime). Jakarta: Raja Grafindo Persada, 2012.

Eddy O.S. Hiariej. Prinsip-prinsip Hukum Pidana. Yogyakarta: Cahaya Atma Pustaka, 2014. 
Dody Tri Purnawinata, Aspek Hukum Dalam Perjudian Secara Online, Halaman 252-271

Eriyantouw Wahid. Keadilan

Restoratif dan Peradilan

Konvensional dalam Hukum

Pidana. Jakarta: Univ. Trisakti, 2009.

Jhony Ibrahim. Teori Dan Metode Penelitian Hukum Normatif. Malang: Bayumedia, 2006.

Joshua Sitompul. Cyberspace, Cybercrimes, Cyberlaw. Jakarta: Tatanusa, 2012.

Moeljatno. Asas-Asas Hukum Pidana. Jakarta: Rineka Cipta, 1993.

Satjipto Rahardjo. Hukum dan Perubahan Sosial: Suatu Tinjauan Teoritis Serta Pengalaman-Pengalaman di Indonesia. Bandung: Alumni, 1983.

Sudarto. Hukum Pidana I. Semarang: Yayasan Sudarto, 1990. 